\title{
PENGARUH PROMOSI, HARGA DAN INOVASI PRODUK TERHADAP KEPUTUSAN PEMBELIAN PADA KENTUCKY FRIED CHICKEN (KFC) SIMPANG MATARAM MEDAN
}

\author{
Sunarti E.Silaban ${ }^{1}$ \\ Elisabeth $^{2}$ \\ Roslinda Sagala ${ }^{3}$ \\ ${ }^{1}$ Program Studi Manajemen Universitas Katolik Santo Thomas. Narti Narti \\ Nartisilaban1603@gmail.com \\ ${ }^{2}$ Dosen Program Studi Manajemen Universitas Katolik Santo Thomas. \\ Elisabeth081996@gmail.com \\ ${ }^{3}$ Dosen Program Studi Manajemen Universitas Katolik Santo Thomas. \\ sagalaroslinda@yahoo.co.id
}

\begin{abstract}
Abstrak
Tujuan penelitian ini adalah untuk mengetahui pengaruh promosi, harga dan inovasi produk terhadap keputusan pembelian KFC Simpang Mataram Medan. Pengumpulan data dilakukan melalui cara penyebaran kuesioner yang dilaksanakan pada 100 pengunjung pada KFC Simpang Mataram Medan. Analisis data pada penelitian ini menggunakan SPSS versi 22. Dari hasil penelitian ini menunjukkan bahwa persamaan regresi berganda adalah $\mathrm{Y}=3,374+0,531 \mathrm{X}_{1}+0,285 \mathrm{X}_{2}+0,149 \mathrm{X}_{3}$ artinya dalam pengujian uji F menunjukkan bahwa Promosi, harga dan inovasi produk berpengaruh positif dan signifikan secara simultan terhadap keputusan pembelian KFC Simpang Mataram Medan ( $F_{\text {hitung }}$ sebesar 30,041 $>F_{\text {tabel }}$ sebesar 2,70). Secara parsial (uji t) menunukkan bahwa promosi berpengaruh positif dan signifikan terhadap keputusan pembelian KFC Simpang Matararam Medan ( $\mathrm{t}_{\text {hitung }} 5,675>1,984$ dan tingkat signifikan sebesar $0,000<0,05$ ), harga berpengaruh positif dan signifikan terhadap keputusan pembelian KFC Simpang Mataram Medan ( $\mathrm{t}_{\text {hitung }} 2,330>1,984$ dan tingkat signifikan 0,022 < 0,05) dan Inovasi produk berpengaruh positif tetapi tidak signifikan terhadap keputusan pembelian sebesar ( $\mathrm{t}_{\text {hitung }} 1,708<1,984$ dengan tingkat signifikan $0,091>0,05$ ) dan nilai koefisien determinasi (R square) sebesar 0,484 Artinya, Keputusan Pembelian dapat dijelaskan oleh Promosi, Harga dan Inovasi Produk sebesar 48,4\%, sedangkan 42,6\% lagi dijelaskan oleh faktor lain yang tidak dijelaskan dalam penelitian ini seperti komunikasi dan keamanan dan lain-lain. Dan dari hasil penelitian dan pembahasan sebaiknya KFC Simpang Mataram Medan semakin mengembangkan dan mempertahankan indikatorindikator dari Promosi, harga dan inovasi produk yang telah ada di KFC Simpang Mataram Medan.
\end{abstract}

Kata kunci : Promosi, Harga, Inovasi Produk, Keputusan Pembelian KFC.

\section{PENDAHULUAN}

Persaingan adalah satu hal yang tidak dapat lepas dari kehidupan manusia, dimana para pelaku bisnis menciptakan tempat yang lebih baik 
dan layak bagi kehidupan manusia. Banyak hal yang mempengaruhi terjadinya persaingan, beberapa di antaranya adalah target pencapaian, inovasi-inovasi di dalam hidup manusia, dan tingkat kreatifitas manusia yang terus meningkat.

Bisnis merupakan suatu kegiatan atau aktivitas yang dilakukan oleh suatu perusahaan untuk memperoleh keuntungan. Saat ini perkembangan usaha bisnis semakin mengalami peningkatan terutama yang sedang berkembang adalah bisnis kuliner, khususnya bisnis restoran cepat saji .

Mobilitas masyarakat yang semakin tinggi dan aktivitas kerja yang sibuk mengakibatkan mereka untuk selalu mencari sesuatu yang bersifat praktis dan instan dalam pemenuhan kebutuhan sehari-hari. Salah satunya dengan mencari makanan dan minuman di luar rumah, untuk memenuhi kebutuhannya. Dapat dikatakan kebiasaan makan direstoran cepat saji telah menjadi bagian yang tak terpisahkan dari kehidupan masyarakat saat ini.

Dengan tingginya minat masyarakat untuk makan di luar rumah tentunya membuat timbulnya persaingan yang ketat di dunia bisnis ini. Sehingga saat ini para pelaku usaha harus mampu memahami kebutuhan pelanggan. Dengan memahami kebutuhan, keinginan dan permintaan pelanggan, maka akan memberikan masukan penting bagi perusahaan untuk merancang strategi pemasaran agar dapat menciptakan peningkatan penjualan. (Kotler dan Armstrong, 2008: 46).

Sehubungan dengan penjelasan diatas, agar perusahaan bisa bertahan hidup dan berkembang dimasa mendatang, maka fenomenafenomena seperti promosi, harga dan inovasi produk tentu harus mendapatkan perhatian yang lebih baik dan serius.

Promosi adalah segala bentuk komunikasi yang digunakan untuk menginformasikan (Adurachman, 2004: 36), Dampak promosi bertujuan untuk membangkitkan keinginan atau merangsang pembelian adalah pelanggan merasa yakin sehingga mau melakukan pembelian. Promosi yang dilakukan oleh KFC Simpang Mataram Medan dengan cara menyediakan paket-paket pembelian dan juga menyediakan paket potongan harga pada moment-moment tertentu seperti Hari Raya Idul Fitri, Natal, Hari Kemerdekaan RI, dan lainnya. Salah satu promo penjualan paket yang dilakukan oleh perusahaan KFC adalah penyajian paket attack. KFC paket attack adalah salah satu menu paket yang paling bertahan dari setiap paket - paket yang disajikan oleh pihak KFC. Paket Attack merupakan promosi penjualan dengan menu sayap ayam goreng crispy, nasi dan segelas pepsi ukuran kecil. 
Faktor seseorang melakukan keputusan pembelian untuk produk paket adalah harga dan produk dalam paket itu sendiri. Harga yang ditawarkan pada paket attack setiap pembelian paket adalah $\mathrm{Rp} 19.000$ (Sesudah pajak), sedangkan jika dibandingkan dengan pembelian masing masing dapat diperoleh harga sayap ayam Crispy Rp 11.500, Pepsi ukuran kecil Rp 5.500 dan nasi Rp 5.500, maka dapat dihitung harga totalnya Rp 22.500 (sesudah pajak).

Harga menurut Kotler dan Amstrong (2008:345) adalah sejumlah uang yang ditukarkan untuk sebuah produk atau jasa, atau jumlah dari nilai yang ditukarkan para pelanggan untuk memperoleh manfaat dari memiliki atau menggunakan suatu produk atau jasa. Sehingga dengan penetapan harga yang tepat akan mampu menciptakan peningkatan volume penjualan. Harga menjadi salah satu faktor dalam melakukan keputusan pembelian, Segala keputusan yang menyangkut harga akan berpengaruh terhadap aspek keuntungan atau profitabilitas perusahaan. Berdasarkan survei pada KFC Simpang Mataram Medan, bahwa harga yang ditawarkan sangat beragam, dari mulai harga Rp 5.000 s.d harga Rp 145.000.

Inovasi produk juga merupakan faktor yang sangat mempengaruhi keputusan pembelian. Inovasi harus mampu membuat produk berbeda dimata konsumen sehingga konsumen lebih tertarik membeli produk tersebut dibandingkan produk pesaing. Salah satu inovasi yang dilakukan oleh KFC Simpang Mataram Medan yaitu meluncurkan menu Praktis dan Breakfast. Adapun menu KFC Praktis diantaranya Chick'N Fillet, Twisty, Fish Fillet, Oriental Bento,dan Burger. Sedangkan untuk menu Breakfast diantaranya, Original Porridge, Scrambled Egg, Pom-Pom, Pancake, Riser, Chicken Porridge, Waffle, French Toast dan CoffleHazelnut.

Berikut beberapa perusahaan yang bergerak dibidang restoran cepat saji sejenis dapat dilihat pada table 1 berikut:

Tabel 1. Restoran cepat saji sejenis di kota Medan

\begin{tabular}{|c|l|}
\hline NO. & \multicolumn{1}{|c|}{ Nama Perusahaan } \\
\hline 1 & KFC \\
\hline 2 & Richeese Factory \\
\hline 3 & McDonald's \\
\hline 4 & A \& W \\
\hline 5 & Texas Fried Chicken \\
\hline 6 & California Fried Chicken \\
\hline 7 & Kebab Turki \\
\hline 8 & Pizza Hut \\
\hline 9 & Hoka-Hoka Bento \\
\hline
\end{tabular}


Berdasarkan Tabel 1 diatas dapat diketahui bahwa terdapat juga pesaing sejenis dari KFC yaitu Richeese Factory, Mc Donald's, A \& W, Texas Chicken, California Fried Chicken, Kebab Turki, Pizza Hut dan Hoka-Hoka Bento. Pesaing sejenis tersebut merupakan pesaing terdekat dari KFC yang menawarkan produk unggulan yang sama yaitu ayam goreng dan perusahaan pesaing tersebut juga sudah dikenal oleh masyarakat luas.

Di bawah ini penulis ingin meneliti melalui jumlah data pengunjung di KFC Simpang Mataram Medan dalam kurun waktu 2017-2018.

Tabel 2 Jumlah data pengunjung tahun 2017- 2018 di KFC Simpang Mataram Medan.

\begin{tabular}{|c|c|c|c|}
\hline No & Bulan & $\begin{array}{c}\text { Jumlah } \\
\text { Pengunjung } \\
\text { 2017(orang) }\end{array}$ & $\begin{array}{c}\text { Jumlah } \\
\text { pengunjung } \\
\text { 2018(orang) }\end{array}$ \\
\hline 1 & Januari & 32.425 & 31.405 \\
\hline 2 & Februari & 29.500 & 29.470 \\
\hline 3 & Maret & 29.247 & 29.147 \\
\hline 4 & April & 28.880 & 26.520 \\
\hline 5 & Mei & 27.325 & 25.320 \\
\hline 6 & Juni & 28.420 & 27.550 \\
\hline 7 & Juli & 28.670 & 26.520 \\
\hline 8 & Agustus & 30.520 & 29.532 \\
\hline 9 & September & 29.125 & 27.227 \\
\hline 10 & Oktober & 28.567 & 28.450 \\
\hline 11 & November & 29.270 & 28.242 \\
\hline \multirow[t]{2}{*}{12} & Desember & 32.570 & 31.679 \\
\hline & Jumlah & 354.519 & 341.062 \\
\hline
\end{tabular}

Sumber :Diolah oleh KFC Simpang Mataram Medan, 28 Maret 2019

Berdasarkan tabel diatas terlihat bahwa jumlah data pengunjung di KFC Simpang Mataram Medan mengalami penurunan sejumlah 13.457 pengunjung selama tahun 2017-2018, yang diakibatkan banyaknya para pesaing sejenis khususnya restoran cepat saji di kota Medan. Hal ini diduga disebabkan oleh adanya pengaruh Promosi, harga dan inovasi produk terhadap keputusan pembelian KFC di Simpang Mataram Medan.

Dari pembahasan di atas ada beberapa peneliti yang mendukung pernyataan ini yaitu Dayu Riki Tantia (2017), dengan judul "Pengaruh kualitas pelayanan, Harga, Promosi, dan kualitas Produk terhadap 
keputusan pembelian pada makanan cepat saji KFC Coffee Kedaton Bandar Lampung". Hasil penelitiannya menunjukkan hasil perhitungan variable kualitas pelayanan (X1) sebesar 0,755 , harga (X2) sebesar 0,797, promosi (X3) sebesar 0,737, kualitas produk (X4) 0,809 dan keputusan pembelian (Y) sebesar 0,828 , dimana pada hal ini r-hitung $<$ r-tabel yaitu 0,444 sehingga kesimpulannya kelima variabel tersebut memiliki reliabilitas tinggi.

Hasil penelitian Nurzannah Harahap (2013), dengan judul "Pengaruh kualitas produk, harga dan promosi terhadap keputusan pembelian mie instant merek sedaap pada mahasiswa asrama putri Universitas Sumatera Utara". Hasil penelitiannya menunjukkan nilai R sebesar 0,803 berarti $80,3 \%$ menunjukkan bahwa hubungan antara kualitas produk, harga dan promosi terhadap keputusan pembelian hubungannya erat. Adjusted R Square sebesar 0,632 berarti 63,2\% faktor-faktor keputusan pembelian dapat dijelaskan oleh kualitas produk, harga dan promosi. Sedangkan $36,6 \%$ dijelaskan oleh faktor - faktor lain yang tidak diteliti dalam penelitian ini.

Mengacu pada uraian di atas yang telah dikemukakan, maka penulis merumuskan permasalahan dalam penelitian ini yaitu : Apakah ada Pengaruh Promosi, Harga Dan Inovasi Produk Terhadap Keputusan Pembelian KFC Simpang Mataram Medan?.

Penelitian ini bertuuan untuk mengetahui pengaruh promosi, harga dan inovasi produk terhadap keputusan pembelian pada KFC Simpang Mataram Medan.

\section{TINJAUAN PUSTAKA}

\section{Pengertian Pemasaran}

Menurut Kotler (2007:7) yaitu pemasaran adalah proses sosial yang dengan proses itu individu dan kelompok mendapatkan apa yang mereka butuhkan dan inginkan dengan menciptakan, menawarkan dan secara bebas mempertukarkan produk dan jasa yang bernilai dengan pihak lain. Pemasaran dikembangkan sebagai suatu pola yang tertata dalam suatu sistem yang sering kali disebut sebagai ilmu dan juga dikembangkan dengan cara masing-masing pelaku sehingga disebut improvisasi dan karenanya disebut seni.

Dalam pemasaran tentu menyangkut bagaimana perlu memperhatikan bauran pemasaran. Menurut Kotler dan Armstrong (2001: 98), Marketing Mix (Bauran Pemasaran) adalah campuran dari variabel 
pemasaran yang dapat dikendalikan (controllable variabels) yang digunakan oleh suatu perusahaan untuk mengejar tingkat penjualan yang diinginkan dalam pasar sasaran. Marketing mix terdiri dari 7 unsur, yaitu:

1. Product: Jasa seperti apa yang ingin ditawarkan

2. Price : Bagaimana strategi penentuan harga

3. Promotion : Bagaiman promosi yang haru dilakukan

4. Place : Bagaimana sistem penghantaran ( delivery sistem) yang akan diterapkan

5. People : Tipe kualitas dan kuantitas orang yang akan terlihat dalam pemberian jasa.

6. Process: Bagaimana proses dalam operasi jasa tersebut.

7. Customer Service : Tingkat service yang bagaimana yang akan diberikan kepada konsumen.

\section{Promosi}

\section{Pengertian Promosi}

Menurut Swasta dan Irawan (2005:349) promosi adalah suatu bentuk komunikasi pemasaran yang bertujuan mendorong permintaan, yang dimaksud komunikasi pemasaran adalah aktivitas pemasaran yang berusaha menyebarkan informasi, mempengaruhi dan atau mengingatkan pasar sasaran atas perusahaan dan pada produknya agar bersedia menerima, membeli, dan loyal pada produk atau jasa yang ditawarkan perusahaan yang bersangkutan.

Menurut Husein (2002:35) promosi adalah pengkomunikasian informasi antara penjual dan pembeli atau pihak-pihak lainnya agar produk tersebut dikenal dan akhirnya dibeli. Dari beberapa teori diatas dapat ditarik kesimpulan bahwa promosi adalah kegiatan pengkomunikasian untuk memberikan informasi kepada orang-orang tentang produk yang akan ditawarkan sehingga konsumen tertarik untuk membeli produk atau jasa yang ditawarkan.

\section{Tujuan Promosi}

Menurut Nickels, dkk (2008: 10) promosi bertujuan untuk mempengaruhi masyarakat untuk berpartisipasi dalam pembelian. Promosi juga bertujuan untuk memotivasi masyarakat untuk membeli produk atau jasa sebuah perusahaan, serta menjadi sarana untuk membangun hubungan dengan pelanggan. Tujuan utama promosi adalah modifikasi tingkah laku konsumen, menginfomasikan, mempengaruhi dan membujuk serta 
mengingatkan konsumen sasaran tentang perusahaan dan produk atau jasa yang dijualnya (Swasta \& Irawan, 2005:353).

\section{Harga \\ Pengertian Harga}

Menurut Tjiptono (2006:178), harga dapat diartikan sebagai jumlah uang (satuan moneter) dan atau aspek lain (non moneter) yang mengandung utilitas/kegunaan tertentu yang diperlukan untuk mendapatkan suatu jasa. Harga juga mempunyai arti jumlah uang yang harus konsumen bayarkan untuk mendapatkan suatu produk (Herman,et.al, 2007). Menurut Chandra dalam Tjiptono (2006:179) dikatakan bahwa harga merupakan pernyataan nilai dari suatu produk (a statement of value).

Faktor harga produk selalu menjadi faktor penting dalam proses dalam konteks setiap pembelian pelanggan/konsumen. Konsumen selalu memeriksa informasi harga dan nama merek berbeda ketika mereka membuat penilaian pada ukuran kualitas: kemudahan penggunaan, kegunaan, kinerja, ketahanan dan status (Brucks, Zeithaml \&Amp; Naylor, dalam Rajput,et.al.2012: 487).

Dari pengertian-pengertian di atas, dapat disimpulkan bahwa penetapan harga merupakan keputusan kritis yang menunjang keberhasilan suatu perusahaan.

\section{Tujuan Penetapan Harga}

Menurut Lupiyoadi (2006:100), metode penetapan harga harus dimulai dengan pertimbangan atas tujuan penetapan harga itu sendiri, antara lain:

a. Bertahan; merupakan usaha untuk tidak melakukan tindakan-tindakan yang meningkatkan laba ketika perusahaan sedang mengalami kondisi pasar yang tidak menguntungkan.

b. Memaksimalkan laba; penentuan harga bertujuan untuk memaksimalkan laba dalam periode tertentu.

c. Memaksimalkan penjualan; penetapan harga bertujuan untuk membangun pangsa pasar dengan melakukan penjualan pada harga awal yang merugikan.

d. Gengsi atau prestos; tujuan penetapan harga di sini adalah untuk memposisikan jasa perusahaan tersebut sebagai jasa yang eksklusif.

e. Pengembalian atas investasi (ROI); tujuan penentuan harga didasarkan atas pencapaian pengembalian atas investasi (return on investment-ROI) yang diinginkan. 
Menurut Tjiptono (2004:185), terdapat dua macam tujuan penetapan harga, yaitu tujuan umum dan tujuan spesifik. Adapun masingmasing tujuan tersebut adalah sebagai berikut:

a. Tujuan umum penetapan harga

1) Mengurangi risiko ekonomi dari percobaan produk.

2) Menawarkan nilai yang lebih baik dibandingkan bentuk/kelas produk pesaing.

3) Meningkatkan frekuensi konsumsi.

4) Menambah aplikasi/pemakaian dalam situasi yang lebih banyak.

5) Melayani segmen yang berorientasi pada harga.

b. Tujuan spesifik penetapan harga

1) Menghasilkan surplus sebesar mungkin.

2) Mencapai tingkat target spesifik tetapi tidak berusaha memaksimumkan laba.

3) Menutup biaya teralokasi secara penuh termasuk biaya overhead institutional

4) Menutup biaya penyediaan satu kategori jasa atau produk tertentu (setelah dikurangi biaya overhead institutional dan segala macam hibah spesifik.

5) Menutup biaya penjualan inkremental kepada satu konsumen ekstra.

\section{Inovasi Produk}

\section{Pengertian Inovasi Produk}

Menurut Myers dan Marquis dalam Kotler (2007:36) menyatakan bahwa inovasi produk adalah gabungan dari berbagai macam proses yang saling mempengaruhi antara yang satu dengan yang lain. Jadi inovasi bukanlah konsep dari suatu ide baru, penemuan baru atau juga bukan merupakan suatu perkembangan dari suatu pasar yang baru saja, tetapi inovasi merupakan gambaran dari semua proses-proses tersebut.

Charles, et al. (2002: 30) menyatakan bahwa inovasi merupakan bagian dari kerangka kerja yang menghubungkan aspek budaya perusahaan dengan kemampuan berinovasi serta meningkatkan kinerja perusahaan melalui keputusan membeli konsumen.

Berkaitan dengan uraian diatas, dapat disimpulkan bahwa inovasi produk adalah gambaran dari berbagai proses mulai dari konsep suatu ide baru, penemuan baru dan suatu perkembangan dari suatu pasar yang baru yang saling mempengaruhi antara yang satu dengan yang lain. 


\section{Pengaruh Promosi, Harga dan Inovasi produk Terhadap Keputusan} Pembelian

\section{Pengaruh Promosi Terhadap Keputusan Pembelian}

Promosi adalah segala bentuk aktivitas yang mengiringi operasi penjualan untuk meningkatkan kemungkinan suatu penjualan (Colin, 2003: 28 dalam Susanto, 2006). Promosi adalah semua jenis kegiatan pemasaran yang ditujukan untuk mendorong permintaan (Irawan, 2000:349 dalam Susanto, 2006). Sehingga secara individual variabel promosi berpengaruh terhadap keputusan pembelian. Semakin tinggi promosi maka semakin besar konsumen dalam keputusan pembelian. Dengan ini berarti bahwa promosi mampu mempengaruhi keputusan pembelian konsumen dalam pembelian produk (Susanto, 2006).

Promosi merupakan faktor penting dalam mewujudkan tujuan penjualan suatu perusahaan. Agar konsumen bersedia menjadi langganan, mereka terlebih dahulu harus dapat mencoba atau meneliti barang-barang yang diproduksi oleh perusahaan, akan tetapi mereka tidak akan melakukan hal tersebut jika kurang yakin terhadap barang itu. Disinilah perlunya mengadakan promosi yang terarah, karena diharapkan dapat memberikan pengaruh positif terhadap meningkatnya penjualan.

\section{Pengaruh Harga terhadap Keputusan Pembelian}

Harga adalah jumlah uang yang harus dibayarkan konsumen untuk memperoleh produk. Harga merupakan satu-satunya unsur bauran pemasaran yang memberikan pemasukan atau pendapatan bagi perusahaan, sementara ketiga unsur lainnya (produk, distribusi, dan promosi) menyebabkan timbulnya biaya/ pengeluaran (Kotler dan Amstrong, 2008). Bagi konsumen, harga seringkali digunakan sebagai indikator nilai bilamana harga tersebut dihubungkan dengan manfaat yang dirasakan atas suatu barang atau jasa. Tjiptono(2007) juga menjelaskan bahwa adanya hubungan antara harga dan manfaat dalam keputusan pembelian konsumen telah membuat perusahaan harus memilih suatu harga yang tidak terlalu tinggi maupun terlalu rendah, tetapi suatu harga yang sama dengan nilai persepsi bagi target konsumen.

\section{Pengaruh Inovasi Produk terhadap Keputusan Pembelian}

Inovasi produk merupakan sesuatu yang dipersepsi konsumen sebagai hal yang baru. Sebagai produk baru, produk inovasi diharapkan bisa memenuhi harapan konsumen. Harapan konsumen yang dimaksudkan antara lain mewakili harga, gaya hidup, dan motivasinya. Ketika sebuah 
produk inovasi mampu menghadirkan harapan konsumen maka peluang terjadinya keputusan pembelian konsumen yang besar rmenurut Boone dalam Poloan (2006 : 22).

\section{Keputusan Pembelian}

\section{Pengertian Keputusan Pembelian}

Pengambilan keputusan merupakan suatu kegiatan individu yang secara langsung terlibat dalam mendapatkan dan mempergunakan barang yang ditawarkan. Proses pengambilan keputusan konsumen untuk membeli tidak bisa terjadi tiba-tiba atau dengan sendirinya, pasti terdapat stimulus atau rangsangan dari luar kendali konsumen. Menurut Lambed al,(2001:201) menjelaskan bahwa yang mempengaruhi keputusan pembelian secara kuat dipengaruhi oleh faktor-faktor sebagai berikut:

1. Faktor budaya yang termasuk didalamnya adalah budaya dan nilai, subbudaya

2. Faktor Sosial menunjukkan interaksi sosial antara konsumen dan mempengaruhi sekelompok orang.

3. Faktor Individu termasuk jenis kelamin, umur, keluarga, daur hidup keluarga, pribadi.

4. Faktor psikologis menentukan bagaimana menerima dan berinterkasi dengan lingkungannya dan pengaruh pada keputusan yang akan diambil oleh konsumen yang didalamnya terdiri dari persepsi, motivasi, pembelajaran, keyakinan, dan sikap.

\section{Proses Pengambilan Keputusan}

Perilaku konsumen memainkan peranan penting dalam proses pengambilan keputusan membeli suatu produk. Menurut Philip Kotler dan Keller Kevin, (2008:235) para konsumen melewati lima tahap proses pengambilan keputusan yaitu: pengenalan masalah, pencarian informasi, evaluasi alternatif, keputusan pembelian, dan perilaku pasca pembelian. Namun, para konsumen tidak selalu melewati seluruh lima urutan tahapan ketika membeli produk. Mereka bisa melewati atau membalik beberapa tahap. Akan tetapi, model dalam Gambar 1 menyajikan satu kerangka acuan, karena ia merebut kisaran perimbangan sepenuhnya yang muncul ketika seorang konsumen menghadapi pembelian baru dengan keterlibatan yang tinggi. 
Berikut ini ada 5 tahap proses pengambilan keputusan pembelian yang dilakukakan oleh konsumen.

\begin{tabular}{|c|c|c|c|c|}
\hline $\begin{array}{l}\text { Pengenalan } \\
\text { masalah }\end{array}$ & $\begin{array}{l}\text { Pencarian } \\
\text { informasi }\end{array}$ & $\begin{array}{l}\text { Penilaian } \\
\text { alternatif }\end{array}$ & $\begin{array}{c}\text { Keputusan } \\
\text { membeli }\end{array}$ & $\begin{array}{c}\text { Perilaku } \\
\text { pasca }\end{array}$ \\
\hline
\end{tabular}

\section{Gambar 1 Proses Pengambilan Keputusan}

Sumber : Sumarwan (2012)

Menurut Kotler dan Armstrong, (2008:179-184) Secara rinci, tahap-tahap ters ebut dapat diuraikan sebagai berikut:

a. Pengenalan Masalah; proses pembelian dimulai ketika pembeli mengenal suatu masalah atau kebutuhan. Pengenalan kebutuhan dapat diartikan sebagai persepsi atas perbedaan antara keadaan yang diinginkan dan situasi aktual yang memadai untuk menggugah dan mengaktifkan proses keputusan.

b. Pencarian Informasi ; pencarian merupakan aktivitas termotivasi dari pengetahuan yang tersimpan dalam ingatan atau perolehan informasi dari lingkungan.

c. Evaluasi alternative

Evaluasi alternatif merupakan proses dimana suatu alternatif pilihan disesuaikan dan dipilih untuk memenuhi kebutuhan konsumen. Kompleksitas dari evaluasi akan bervariasi secara dramatis tergantung pada proses khusus yang diikuti konsumen dalam mengambil keputusan untuk dikonsumsi.

d. Keputusan Membeli.

Setelah menentukan kepercayaan terhadap suatu merek, maka konsumen membentuk suatu maksud pembelian untuk membeli produk yang paling disukai.

e. Perilaku Pasca Pembelian.

Setelah membeli produk, konsumen akan mengalami level kepuasan atau ketidakpuasan tertentu. Tugas pemasar tidak berakhir saat produk dibeli, melainkan berlanjut hingga periode pasca pembelian. Pemasar harus memantau kepuasan pasca pembelian, tindakan pasca pembelian, dan pemakain produk pasca pembelian. 


\section{METODE PENELITIAN}

\section{Populasi dan Sampel \\ Populasi}

Pengertian populasi menurut Sugiyono (2013:148) adalah wilayah generalisasi yang terdiri atas obyek/subyek yang mempunyai kualitas dan karakteristik tertentu yang ditetapkan oleh peneliti untuk dipelajari dan kemudian ditarik kesimpulannya. Populasi dalam penelitian ini adalah seluruh pengunjung di KFC Simpang Mataram Medan selama satu tahun sebanyak 341.062 pengunjung pada tahun 2018.

\section{Sampel}

Sampel merupakan sebagian dari populasi yang diharapkan dapat mewakili populasi (Sugiyono, 2013:81). Sampel sebaiknya memenuhi kriteria yang dikehendaki, jumlah anggota sampel yang paling tepat digunakan dalam penelitian tergantung pada tingkat kesalahan yang dikehendaki.

Pada penelitian ini pengambilan jumlah responden menggunakan rumus Slovin ( Husein Umar 2008:78) sampel yang akan ditentukan oleh peneliti dengan presentase kelonggaran ketidaktelitian adalah sebesar $10 \%$.

$$
\mathrm{n}=\frac{N}{1+N \varepsilon^{2}}
$$

Keterangan :

$\mathrm{n}=$ Ukuran sampel

$\mathrm{N}=$ Ukuran populasi

$\varepsilon^{2}=$ error atau tingkat kesalahan

Maka dari data tersebut didapatkan ukuran sampel dengan menggunakan rumus Slovin sebagai berikut

$\mathrm{n}=\frac{341.062}{1+341.062\left(0,1^{2}\right)}=99,97=100$ (dibulatkan)

Maka dapat disimpulkan, sampel pada penelitian ini menggunakan 100 orang responden. Teknik pengambilan sampel adalah accidental sampling, yaitu teknik penentuan sampel berdasarkan kebetulan yaitu siapa saja yang secara kebetulan ditemui oleh peneliti dan memiliki kriteria yang sesuai maka akan dijadikan sebagai sampel.

\section{Operasionalisasi Variabel}

Operasionalisasi variabel adalah batasan pokok permasalahan yang diteliti dan diamati sesuai dengan perumusan masalah. Variabel yang akan diteliti dalam penelitian ini adalah: 
Tabel 3 Operasionalisasi Variabel

\begin{tabular}{|c|c|c|c|}
\hline Variabel & Defenisi Variabel & Indikator & $\begin{array}{c}\text { Skala } \\
\text { Ukuran }\end{array}$ \\
\hline $\begin{array}{l}\text { Promosi } \\
\text { (X1) }\end{array}$ & $\begin{array}{l}\text { Promosi adalah } \\
\text { pengkomunikasian } \\
\text { informasi antara penjual } \\
\text { dan pembeli atau pihak- } \\
\text { pihak lainnya agar } \\
\text { produk tersebut dikenal } \\
\text { dan akhirnya dibeli. }\end{array}$ & $\begin{array}{l}\text { 1. Periklanan } \\
\text { 2. Promosi Penjualan } \\
\text { 3. Publisitas dan } \\
\text { Humas } \\
\text { 4. Informasi dari mulut } \\
\text { ke mulut } \\
\text { 5. Pemasaran } \\
\text { Langsung }\end{array}$ & Likert \\
\hline $\begin{array}{l}\text { Harga } \\
\text { (X2) }\end{array}$ & $\begin{array}{l}\text { Harga adalah jumlah } \\
\text { uang yang } \\
\text { dibayarkan } \\
\text { untuk konsumen } \\
\text { produk. }\end{array}$ & $\begin{array}{l}\text { 1. Keterjangkauan } \\
\text { Harga } \\
\text { 2.Diskon atau } \\
\text { potongan harga } \\
\text { 3. Cara pembayaran }\end{array}$ & Likert \\
\hline $\begin{array}{c}\text { Inovasi } \\
\text { Produk } \\
\text { (X3) }\end{array}$ & \begin{tabular}{lr}
\multicolumn{1}{c}{ Inovasi } & $\begin{array}{r}\text { merupakan } \\
\text { bagian dari } \\
\text { kerangka } \\
\text { kerja }\end{array}$ \\
menghubungkan & aspek \\
budaya & perusahaan \\
dengan & kemampuan \\
berinovasi & serta \\
meningkatkan & kinerja \\
perusahaan & melalui \\
keputusan & membeli \\
konsumen. &
\end{tabular} & $\begin{array}{l}\text { 1. Produk baru bagi } \\
\text { dunia } \\
\text { 2. Lini produk baru } \\
\text { 3. Tambahan pada lini } \\
\text { produk yang telah } \\
\text { ada. } \\
\text { 4. Perbaikan produk } \\
\text { yang telah ada. } \\
\text { 5. Penentuan kembali } \\
\text { 6. Pengurangan biaya }\end{array}$ & Likert \\
\hline $\begin{array}{c}\text { Keputusan } \\
\text { Pembelian } \\
\text { (Y) }\end{array}$ & $\begin{array}{l}\text { Pengambilan keputusan } \\
\text { merupakan suatu } \\
\text { kegiatan individu yang } \\
\text { secara langsung terlibat } \\
\text { dalam mendapatkan dan } \\
\text { mempergunakan barang } \\
\text { yang ditawarkan }\end{array}$ & $\begin{array}{l}\text { 1. Kemantapan pada } \\
\text { sebuah produk } \\
\text { 2. Kebiasaaan dalam } \\
\text { membeli produk } \\
\text { 3. Memberikan } \\
\text { rekomendasi kepada } \\
\text { orang lain } \\
\text { 4. Melakukan } \\
\text { pembelian ulang }\end{array}$ & Likert \\
\hline
\end{tabular}

Sumber : Diolah Penulis 


\section{Teknik Pengumpulan Data}

\section{Kuesioner}

Data yang dibutuhkan dalam penelitian ini adalah data primer yaitu data yang diperoleh dari hasil penyebaran kuesioner kepada pengunjung KFC Simpang Mataram Medan.

\section{Dokumentasi}

Teknik dokumentasi dilakukan dengan mengumpulkan data yang sudah diolah sebelumnya berupa jumlah pengunjung KFC Simpang Mataram Medan.

\section{Teknik Analisis Data}

Teknik analisis data yang digunakan peneliti dalam penelitian ini adalah dengan menggunakan: Regresi Linier Berganda

Metode regresi linier berganda, dimana penelitian dilakukan untuk mengetahui ada atau tidaknya pengaruh variabel Promosi (X1), Harga (X2) dan Inovasi Produk (X3) terhadap keputusan pembelian (Y). Data yang dianalisis menggunakan program komputer yaitu program SPSS. Model regresi linier berganda yang digunakan adalah sebagai berikut:

Keterangan:

$$
\mathrm{Y}=\beta 0+\beta 1 \mathrm{X} 1+\beta 2 \mathrm{X} 2+\beta 3 \mathrm{X} 3+\varepsilon
$$

$$
\begin{aligned}
& Y=\text { Keputusan Pembelian } \\
& \alpha=\text { Konstanta dari keputusan regresi } \\
& \beta 0, \beta 2, \beta 3=\text { Koefisien regresi berganda } \\
& X 1=\text { Promosi } \\
& X 2=\text { Harga } \\
& X 3=\text { Inovasi Produk }
\end{aligned}
$$

Untuk menguji pengaruh promosi, harga dan inovasi produk terhadap keputusan pembelian dilakukan dengan;

\section{Uji t (Untuk mengetahui pengaruh masing-masing variabel bebas terhadap variabel terikat)}

1. $\mathrm{H}_{0}: \beta \mathrm{i}=0$. Artinya tidak ada pengaruh yang signifikan dari Promosi (X1), Harga (X2), Inovasi Produk (X3) secara parsial terhadap Keputusan Pembelian (Y) di KFC Simpang Mataram Medan .

$\mathrm{H}_{1}: \beta \mathrm{i} \neq 0$. Artinya ada pengaruh yang signifikan dari pengaruh Promosi (X1), Harga (X2), Inovasi Produk (X3) secara parsial terhadap Keputusan Pembelian (Y) di KFC Simpang Mataram Medan.

2.Menentukan tingkat signifikan 95\% ( $\alpha=0,05 \%)$ 
3. Statistik uji $\mathrm{t}$ :

$$
\mathrm{t}=\frac{b}{s b}
$$

4.Kriteria Pengujian :

$\mathrm{H}_{0}$ diterima jika : $\mathrm{t}_{\text {hitung }} \leq \mathrm{t}_{\text {tabel }}$

$\mathrm{H}_{1}$ ditolak jika : $\mathrm{t}_{\text {hitung }}>\mathrm{t}_{\text {tabel }}$

\section{Uji F ( Untuk mengetahui pengaruh secara menyeluruh)}

1. $\mathrm{H}_{0}: \beta \mathrm{i}=0$. Artinya tidak ada pengaruh yang signifikan dari pengaruh Promosi (X1), Harga (X2), Inovasi Produk (X3) secara simultan terhadap Keputusan Pembelian (Y) di KFC Simpang Mataram Medan

$\mathrm{H}_{1}: \beta \mathrm{i} \neq 0$. Artinya ada pengaruh yang signifikan dari pengaruh Promosi (X1), Harga (X2), Inovasi Produk (X3) secara simultan terhadap Keputusan Pembelian (Y) di KFC Simpang Mataram Medan.

2. Menentukan tingkat signifikan $95 \%(\alpha=0,05 \%)$

3. Statistik uji F : $\quad \mathrm{Fh}=\frac{R 2 / k}{(1-R 2) /(n-k-1)}$

4. Kriteria Pengujian :

$\mathrm{H} 0$ diterima jika $\mathrm{F}_{\text {hitung }} \leq \mathrm{F}_{\text {tabel }}$

$\mathrm{H} 1$ ditolak jika $\mathrm{F}_{\text {hitung }}>\mathrm{F}_{\text {tabel }}$

\section{HASIL PENELITIAN DAN PEMBAHASAN}

KFC Simpang Mataram menjadi perhitungan bagi pihak manajemen restoran KFC di Medan, karena merupakan pusat outlet KFC yang ada di kota Medan. KFC ini terletak di Jl. Gajah Mada no.14 Simpang Mataram Medan. KFC ini berdiri sejak pertengahan Tahun 1989, KFC ini mempunyai luas area $766,1 \mathrm{~m}^{2}$ dengan kapasitas 270 sit dan 8 sofa, dan memiliki jumlah karyawan sebanyak 56 orang.

Lokasi KFC ini merupakan tempat yang sangat strategis karena letaknya dekat dengan sekolah, daerah perkantoran dan daerah bisnis lainnya (seperti Toko buku Gramedia, Natasha Skin care, toko jual beli mobil, dan lainnya). Sehingga tempat ini selalu ramai dikunjungi oleh masyarakat luas baik anak sekolahan, karyawan perusahaan, ataupun pengunjung dari Toko buku Gramedia. KFC ini menyediakan fasilitas yang lebih lengkap dan luas dibandingkan dengan outlet KFC lainnya yaitu terdapat suatu ruangan/ tempat khusus bagi konsumen yang ingin merayakan ulang tahun. Konsumen yang ingin merayakan ulang tahun tersebut akan diberikan potongan harga bila memesan minimal 30 paket combo dan akan disediakan master ceremony (MC) dan tape music oleh pihak KFC tersebut. Selain itu di KFC ini terdapat fasilitas musholla, tempat permainan anak-anak serta sofa yang besar yang 
membuat konsumen merasa nyaman di tempat tersebut selama menikmati produk KFC.

\section{Pengujian hipotesis}

a. Uji Simultan (Uji F)

Uji simultan dilakukan untuk menunjukkan bahwa promosi, harga dan inovasi Produk berpengaruh secara simultan dan signifikan terhadap keputusan pembelian.

Tabel 4 ANOVA A $^{a}$

\begin{tabular}{|c|c|c|c|c|c|}
\hline Model & $\begin{array}{l}\text { Sum of } \\
\text { Squares }\end{array}$ & Df & $\begin{array}{c}\text { Mean } \\
\text { Square }\end{array}$ & $F$ & Sig. \\
\hline 1 Regression & 476.580 & 3 & 158.860 & 30.041 & $.000^{\mathrm{b}}$ \\
\hline Residual & 507.660 & 96 & 5.288 & & \\
\hline Total & 984.240 & 99 & & & \\
\hline
\end{tabular}

a. Dependent Variable: totx 4

b. Predictors: (Constant), totx3, totx2, totx1

Sumber : data diolah dengan spss

Berdasarkan Tabel 4 di atas menunjukkan bahwa Promosi, Harga dan Inovasi Produk secara simultan terdapat pengaruh signifikan terhadap keputusan pembelian KFC Simpang Mataram Medan. Pengaruh tersebut ditunjukkan pada nilai $F_{\text {hitung }}$ sebesar 30,041 $>F_{\text {tabel }}$ sebesar 2,70, dengan tingkat signifikansi $0,000<0,05$ sehingga $\mathrm{H}_{0}$ ditolak dan $\mathrm{H}_{\mathrm{i}}$ diterima. Artinya Promosi, Harga dan Inovasi Produk berpengaruh secara simultan dan signifikan terhadap keputusan pembelian KFC Simpang Mataram Medan.

b. Uji Parsial (Uji t)

Uji parsial dilakukan untuk mengetahui pengaruh secara parsial antara variabel bebas terhadap variabel terikat berikut :

Tabel 5 Coefficients $^{\text {a }}$

\begin{tabular}{|ll|r|r|r|r|r|}
\hline \multirow{2}{*}{ Model } & \multicolumn{2}{|c|}{$\begin{array}{c}\text { Unstandardized } \\
\text { Coeffic ients }\end{array}$} & $\begin{array}{c}\text { Standardized } \\
\text { Coefficients }\end{array}$ & \multirow{2}{*}{$\mathrm{t}$} & \multirow{2}{*}{ Sig. } \\
\cline { 2 - 5 } & \multicolumn{1}{|c|}{$\mathrm{B}$} & \multicolumn{1}{c|}{$\begin{array}{c}\text { Std. } \\
\text { Error }\end{array}$} & \multicolumn{2}{|c|}{ Beta } & & \\
\hline 1 & (Constant) & 3.374 & 3.745 & & .901 & .370 \\
totx1 & .531 & .094 & .501 & 5.675 & .000 \\
totx2 & .285 & .122 & .203 & 2.330 & .022 \\
totx3 & .149 & .087 & .136 & 1.708 & .091 \\
\hline
\end{tabular}

a. Dependent Variable: tot 4

Sumber : data diolah dengan spss 
Tabel 5 menunjukkan secara parsial pengaruh masing-masing variabel bebas terhadap variabel terikat dengan $\alpha=5 \%$ sehingga diperoleh nilai $t_{\text {tabel }}$ sebesar 1,984 dengan ketentuan $t_{\text {hitung }}>t_{\text {tabel }}$ dan untuk menentukan signifikansi variabel bebas dengan variabel terikat maka dilihat dari nilai signifikan harus lebih kecil dari $\alpha=5 \%$. Maka dari tabel dapat diketahui bahwa, nilai uji $t_{\text {hitung }}$ untuk variabel Promosi sebesar 5,675 $>1,984$ dan tingkat signifikan sebesar 0,000 $<0,05$ sehingga dengan memperhatikan nilai $t_{\text {tabel }}$ (dua arah) maka, $\mathrm{H}_{\mathrm{o}}$ ditolak dan $\mathrm{H}_{\mathrm{i}}$ diterima. Artinya, Promosi berpengaruh secara parsial dan signifikan terhadap keputusan pembelian KFC Simpang Mataram Medan.

Nilai uji $t_{\text {hitung }}$ untuk variabel Harga sebesar 2,330 > 1,984 dan tingkat signifikan $0,022<0,05$ sehingga dengan memperhatikan nilai $t_{\text {tabel }}$ (dua arah) maka, $\mathrm{H}_{\mathrm{o}}$ ditolak dan $\mathrm{H}_{\mathrm{i}}$ diterima. Artinya, Harga berpengaruh secara parsial dan signifikan terhadap keputusan pembelian KFC Simpang Mataram Medan. Nilai uji thitung untuk variabel Inovasi Produk sebesar $1,708<1,984$ dan tingkat signifikan $0,091>0,05$ sehingga dengan memperhatikan nilai $\mathrm{t}_{\text {tabel }}$ (dua arah) maka, $\mathrm{H}_{\mathrm{o}}$ diterima dan $\mathrm{H}_{\mathrm{i}}$ ditolak. Artinya, Inovasi produk berpengaruh secara parsial dan tidak signifikan terhadap keputusan pembelian KFC Simpang Mataram Medan.

\section{Persamaan Regresi Linear Berganda}

Teknik analisis data yang digunakan adalah regresi linear berganda yang berguna untuk mengetahui pengaruh Promosi, Harga dan Inovasi Produk terhadap keputusan pembelian KFC Simpang Mataram Medan. Pengolahan data dilakukan dengan menggunakan program SPSS (Statistical Program for Social Sciences) versi 22.

Berdasarkan hasil uji pada tabel 5 maka, model regresi linier berganda dapat dirumuskan sebagai berikut :

$$
Y=3,374+0,531 X_{1}+0,285 X_{2}+0,149 X_{3}
$$

1. Nilai 3,374 adalah nilai konstanta yang artinya ketika variabel $X$ (Promosi, Harga dan Inovasi Produk ) dianggap konstan atau tidak ada perubahan maka besarnya variabel Y (Keputusan Pembelian) adalah sebesar 3,374

2. Nilai 0,531 pada variabel Promosi (X1) artinya bila $X_{1}$ dinaikkan 1 satuan maka keputusan Pembelian (Y) akan naik sebesar 0,531.

3. Nilai 0,285 pada variabel Harga (X2) artinya bila X2 dinaikkan 1 satuan maka keputusan pembelian (Y) akan naik sebesar 0,285.

4. Nilai 0,149 pada variabel Inovasi Produk (X3) artinya bila X3 dinaikkan 1 satuan maka Keputusan Pembelian (Y) akan naik sebesar 0,149. 
Jadi, dari persamaan regresi linier berganda diatas dapat disimpulkan bahwa Promosi, Harga dan Inovasi Produk berpengaruh signifikan terhadap Keputusan Pembelian di KFC Simpang Mataram Medan. Hal ini dapat dilihat dari nilai koefisien regresinya yang bertanda positif. Dengan kata lain, jika Promosi , Harga dan Inovasi Produk sesuai dengan yang diharapkan oleh konsumen maka konsumen KFC Simpang Mataram Medan akan merasa puas dan sesuai dengan harapannya.

\section{KESIMPULAN DAN SARAN}

\section{Kesimpulan}

1. Persamaan Regressi Linier berganda yang diperoleh adalah: $\mathbf{Y}=\mathbf{3 , 3 7 4}+$

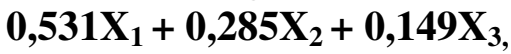

2. Promosi, Harga dan Inovasi Produk berpengaruh positif dan signifikan terhadap keputusan pembelian pada KFC Simpang Mataram Medan

3. Hasil Uji F , bahwa Promosi, Harga dan Inovasi Produk secara simultan berpengaruh positif dan signifikan terhadap keputusan pembelian pada KFC Simpang Mataram Medan

4. Hasil Uji t , bahwa Promosi, Harga secara parsial berpengaruh positif dan signifikan terhadap keputusan pembelian pada KFC Simpang Mataram Medan

5. Hasil uji $\mathrm{t}$, bahwa Inovasi roduk berengaruh tapi tidak signifikan terhadap keputusan pembelian pada KFC Simpang Mataram Medan

\section{Saran}

1. KFC Simpang Mataram Medan diharapkan dapat terus meningkatkan promosi dengan cara meningkatkan desain atau jenis promosi yang menarik dan dapat mudah dimengerti oleh konsumen,dan dapat mempengaruhi konsumen sehingga terciptanya keputusan pembelian.

2. KFC Simpang Mataram Medan diharapkan manajemennya harus lebih memperhatikan faktor harga dan perlu adanya pertimbangan terhadap harga yang diputuskan, agar seluruh konsumen dari segala lapisan sanggup untuk membeli produk KFC

3. KFC Simpang Mataram Medan diharapkan dapat terus melakukan inovasi produk, yang merupakan produk baru bagi dunia kuliner, agar konsumen tertarik dan melakukan pembelian ulang terhadap produk yang diberikan perusahaan. 


\section{DAFTAR PUSTAKA}

Arikunto, Suharsimi, 2002, Metodologi Penelitian. Penerbit PT. Rineka Cipta. Jakarta.

Astari, Tuti. (2017), "Pengaruh harga, kualitas produk dan promosi penjualan terhadap keputusan pembelian produk makanan ringan hasil olahan laut dikota tanjung pinang. Skripsi. Fakultas Ekonomi, Universitas Riau.

Harahap, Nurzannah, (2013), "Pengaruh kualitas produk, harga dan promosi tehadap keputusan pembelian mie instant merek sedaap pada mahasiswa asrama putri Universitas Sumatera Utara”. skripsi. Fakultas Ekonomi dan Bisnis, Universitas Sumatera Utara.

Hartono, Jogiyanto, 2004, Metodologi Penelitian Bisnis, BPFE, Yogyakarta.

Hersona, S.G.W., Muslihat, dan Setyawan, T. 2013, Analisis Pengaruh Bauran Promosi terhadap Keputusan Pembelian Jasa di Lembaga Pendidikan Speaking Karawang. Jurnal Manajemen. Vol.10. No. 3 April 2013. h. 1149-1159.

Irawan, 2000, Manajemen Pemasaran Modern, Edisi 2, Yogyakarta : Liberty.

Kotler, Philip, 2000, Manajemen Pemasaran, Edisi Milenium, Jakarta, Prehallindo

Lupiyoadi, Rambat dan A. Hamdani. 2006, Manajemen Pemasaran Jasa. Edisi Kedua. Jakarta; Salemba Empat.

Sudarsono, D. S dan Kurniawati, Dyah, 2013, Elemen Ekuitas Merek Dalam Keputusan Pembelian Laptop. Vol. 1 No. 1

Swastha, Basu dan Irawan, 2001, Manajemen Pemasaran Modern. Yogyakarta: Liberty.

Tamamudin, 2012. Analisis Pengaruh Pengenalan Merek, Persepsi Kualitas, Harapan Konsumen dan Inovasi Produk terhadap Keputusan Membeli Dan Dampaknya Pada Loyalitas Konsumen 
(Studi Kasus: Produk Batik Sutra Halus Merek Tamina). Jurnal Penelitian Vol. 9, No. 2,November 2012. Hlm. 283-300.

Tantia, D. (2017) "Pengaruk kualitas pelayanan, harga, promosi dan kualitas produk terhadap keputusan pembelian pada makanan cepat saji KFC Coffee Kedaton Bandar Lampung". Skripsi, Fakultas Ekonomi, Universitas Lampung

Tjiptono, Fandy. 2006, Manajemen Jasa. Yogyakarta:Penerbit Andi.

Ujianto, Abdurachman, 2004, Jurnal Manajemen \& Kewirausahaan Vol. 6, No. 1, Maret 2004: 34 -53Analisis Faktor-Faktor yang Menimbulkan Kecenderungan Minat Beli Konsumen Sarung (Studi Perilaku Konsumen Sarung di Jawa Timur), Staf Pengajar Fakultas Ekonomi,Universitas 17 Agustus 1945 Surabaya. 